\title{
Water Demand Assessment of Addis Kidam Town, Awi Zone, Amhara Region, Ethiopia
}

\author{
Mr. Yitbarek Andualem Mekonnen \\ Lecturer, Department of Hydraulic and Water Resources Engineering, Debre Tabor University, \\ Debre Tabor, Ethiopia
}

\begin{abstract}
Adequate quantity and quality of water demand is the most important for one town, as well as each individual to develop their economy in different aspects. The main objective of this study is to assess and provide sufficient and safe water demand of Addis Kidam town, Ethiopia. Existing water demand and sources of water supply is not sufficient for all types of demand at current time in study town, it requires more than half of addition water demand. The finding of this study exposed that, existing water supply has more problems, these are the rapid growth rate of population, lack of funding and loss of water leakages. The projected population of town for first and second phase is 37181 and 45640 respectively by using geometric increasing method. Estimated demand of the town is based on types of mode of service and economic status of study area is $13796.84 \mathrm{~m}^{3} / \mathrm{d}$ and $20423.36 \mathrm{~m}^{3} / \mathrm{d} \mathrm{of}$ maximum daily demand and $20971.2 \mathrm{~m}^{3} / \mathrm{d}$ and $31043.51 \mathrm{~m}^{3} / \mathrm{d}$ of peak hourly demand of the town for first and second phase respectively. The existing water source is covers only $33.5 \%$ and $22.63 \%$ of total current and future maximum daily demands of town communities of first and second phase. At current time needed additional water sources, which is $106.18 \mathrm{l} / \mathrm{s}$ and $183 \mathrm{l} / \mathrm{s}$ of maximum daily demand and peak hourly demand respectively to meet current water demand of town communities for first and second phase of design period. Capacity of services reservoir for first and second phase is $3000 \mathrm{~m}^{3}$ and $5350 \mathrm{~m}^{3}$ respectively throughout design period. Totally existing water sources and demand is not adequate quantity and quality for town population current and future time.
\end{abstract}

Keywords: Population forecasting: Demand assessment: Water source: Capacity of raising main: Capacity of collection chamber: Capacity service reservoir.

DOI: $10.7176 / \mathrm{JEES} / 11-9-02$

Publication date:September $30^{\text {th }} 2021$

\section{INTRODUCTION}

Adequate quantities and quality of water supply is the most significant through the world for living, developing one town or city and for any actives which required water (Emeike et al., 2017). Adequate amounts and quality of water demand is the most important for one town, as well as for individual persons to develop their economy in different aspects, such as direct or indirect use of water production for their work.

Water is the most fundamental need for all living things like human, animals, and plants, without its existence, will be impossible on land for all living things. Along with air, water is the most necessary source for survival on the earth (Kumar and Desta, 2018).

Most of the developing country like Ethiopia has still very little coverage of potable water supply and sanitation that has resulted the citizens to be suffered with water born and water related diseases (Adegbehin et al., 2016 and Girmay et al., 2017).

Ethiopia is a country, which have adequate amounts of natural water sources that means groundwater sources and surfaces water sources, but it has not adequate quantity and quality of domestic water supply, industrial water demand, commercial and institutional water demand and public water demand throughout the country every year, especial study area (Dagnew et al., 2017).

Study area is Addis Kidam town in Fegita Lekoma worda, Awi zone, Amhara regional state, Ethiopia. Study town have inadequate quantities and quality water supply and sanitation system. Currently Addis Kidam town have one spring with yield of 7.51/s and one hand dug well water sources constructed during 1972 year. According to rough estimation around 4 litre/sec amount of Water escaped/leaked from spring capping structure. But this source is not sufficient quantity and quality water for current numbers of town population, because the study town is capital town of Fegita Lekoma worda. Due to this reason the numbers of town population increase rapidly year to year or day to day without considering any infrastructure construction like domestic water supply. The population migrate from rural to urban area and also urban to urban area to find better jobs, facilities like electricity, piped water supply, transport, health center, education, etc.

Other major problems of existing water supply are decreasing amounts of existing water sources and failure of electric power to pump water from sources to services reservoir every day (Manoj and Junil, 2015), and also there is not good distribution system and services reservoir capacity is less compared to daily water demand for town communities, which is $75 \mathrm{~m}^{3}$.

Therefore, town communities to get piped water supply maximum 3-4 days for 4-5 hours by dividing into zone, but the quantity of water is not the same throughout the town. The systems of water supply in study town is 
intermittent system due to lack of adequate quantity of water demand in town, especially new expanded area is not totally gotten piped water supply, in North and South direction of town. Due to this reason $85 \%$ of town communities fetch daily domestic water demand from unprotected and unsafe water sources far from their home every day to meet their daily demand for different purposes. They waste more time to collect their domestic water demand every day throughout the year. This causes water borne diseases, like Typhoid fever, Amoeba, Jerrid and etc and damage physical, especially children and women (Adane et al., 2017 and Alua et al., 2019). Because in Ethiopia collecting fetch domestic water supply is the women and children. Therefore, more women and children do not participate on their own economical productivities and education and also children cannot effectively learn their education on time (Akkaraboyina and Adem, 2018).

\section{Objectives of study}

General aim of this studying is to forecast feature population of town and analysis required water demand assessments of town communities. Specific objectives of study: -

$>$ To improve existing water supply system

$>$ To fix design period of project

$>$ To select the best method of population forecasting and forecast feature population of town

$>$ To calculate total water demand assessments

$>$ To determine capacity of water sources

$>$ Determine capacity of raising main pipe and collection chamber

$>$ To determine capacity of service reservoir

\section{Methodology of study}

\subsection{Description of the Study Area}

The study area is Addis Kidam town, is the capital town of Fagita Lekoma Woreda in Awi zone of Amhara regional state, Ethiopia. It is located at $100 \mathrm{~km}$ from the region capital town of Bahir Dar town, $17 \mathrm{~km}$ from zone capital town of Injibara.

The woreda has 29 kebeles of which 2 are urban and 27 are rural kebeles with total area of 67,733 ha. There is 24-hour power supply in the study area and telecommunication access.

As per the Ethiopian temperature zoning $75 \%$ of the woreda is classified as Dega and $25 \%$ is classified under woinadega climatic zone. The temperature record in the woreda ranges from $20^{\circ} \mathrm{c}$ to $22^{\circ} \mathrm{c}$ in the woreda and the annual precipitation rages from $1,500 \mathrm{~mm}$ to $2,500 \mathrm{~mm}$ with an average record of $2000 \mathrm{~mm}$. Location of the study area is shown below Figure 1.

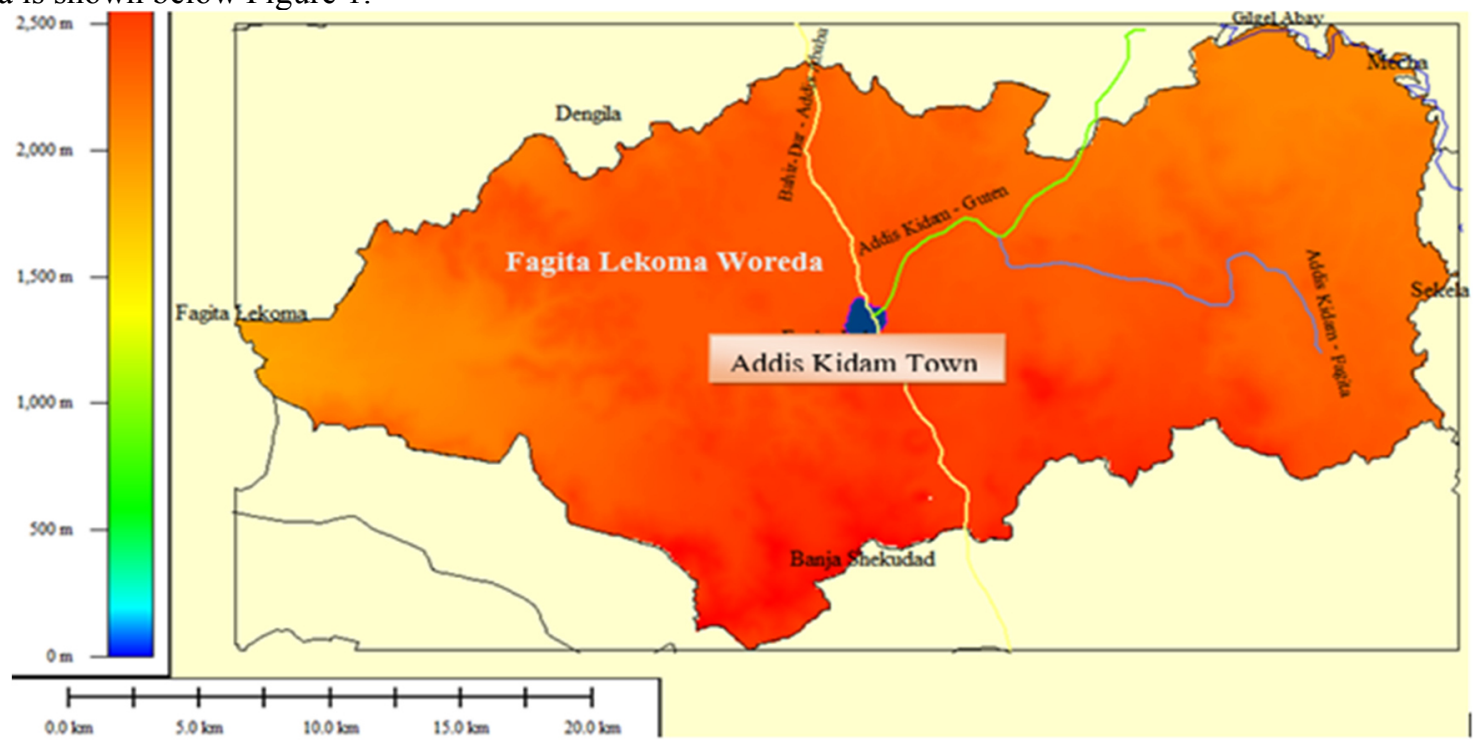

Figure.1: Map of Fagita Lekoma Woreda and Addis Kidam town, Ethiopia (www. amharabofed.gov.et)

\subsection{Methodology of the Study}

Methodology of this study is to collect necessary data, analysis and interpretation of the study by excel, tables and figures. Methods of data collection is household questionnaire, group discussion, personal observation and interview with stakeholders of study town like, administration office, health center, education center, water, irrigation and energy development offices and households of town about the problems of existing water supply in study area. 


\subsection{Data Collection and Types of Data}

There are two types of data, which are primary and secondary data sources. The primary data is collected from households, field observation starting from existing water sources up to distribution systems, by group discussion and interview some selected stakeholders of town. Many different qualitative and quantitative data are collected from secondary sources, these data are collected from literature reviews of scientific journals and written documents from different offices, like water supply and sanitation office, water, irrigation and energy offices, health center, education center, administration office and other office related to water sources.

\subsection{Methods of Data Analysis}

After completion relevant data to analysis and interoperate by using excel, tables and figures and also forecast future population and calculate maximum and peak hourly demands of town for future time and design the capacity of necessary components of water supply starting from sources of water supply up to capacity of service reservoir of study area.

\section{Design Period and Population Forecasting}

\subsection{Design Period}

Design periods of water supply system is neither long nor short depends of different factors, such as funds, duration of construction materials (like treatment pants, pumping house and distribution systems), anticipated expansion the town and the rate of interest on the loan taken. Due to these reasons the design period of this study town is 20 years, starting from 2022 up to 2042 years. This design period is divided into two phases, first phase is 2022 up to 2032 and second phase is 2032 up to 2042 years.

\subsection{Population Forecasting}

Population forecasting is the most significant for one town or city to implement any infrastructures, like domestic water supply, road access, developments of town by economy, establish school and health center of town, and any others (Farah and Yonis, 2015). Due to these reasons forecasting of future population of study town is the most important to determine the future water demands of the study town depends on existing numbers of population by using different methods, but a country of Ethiopia mostly used four methods by comparing their percentage error. These methods are Arithmetic increasing, Geometric increasing, Incremental Increasing and Exponential growth rate or Central Statistics Authority (CSA) methods. The Central Statistics Authority (CSA) is a recognized body in Ethiopia to determine the official population figures and growth rates, that should be taken for any development activity throughout the country.

According to 2007 Census, the population in 2007 was 8,906. When projected to 2016, it is around 15,684. This show there is high population movement from rural surrounding areas to Addis Kidam town as mentioned by administration offices. During studying time $80 \%$ of the data collected from the Woreda administration Planning, Monitoring and Evaluation section after comparing different population data sources and considering existing population settlement and density of the town. Therefore, the target base population of the town in 2018 is 22,100 , this shown below table 1 .

Table 1. base population

\begin{tabular}{|c|c|}
\hline year & population \\
\hline 2007 & 8906 \\
\hline 2014 & 12120 \\
\hline 2016 & 15684 \\
\hline
\end{tabular}

Sources: - from Census data and administration office of study town

Growth Rate of Town Population: - General there are three major factors, which affect the growth rate of population, which are Births, it increases the numbers of population, Death, it decreases the numbers of population and Migration, it increases or decrease the numbers of one town population. According to the central statistics Authority country level population growth rates, the growth rates used to forecast population in the project area are listed below Table.

Table 2: CSA country level population growth rates

\begin{tabular}{|c|c|c|c|c|c|}
\hline Year & $2015-2020$ & $2020-2025$ & $2025-2030$ & $2030-2035$ & $2035-2042$ \\
\hline Growth rate & $4.1 \%$ & $4 \%$ & $3.8 \%$ & $3.6 \%$ & $3.5 \%$ \\
\hline
\end{tabular}

Source: The 2006 Population \& Housing Census of Ethiopia Results for Amhara Region, Volume II Analytical Report.

Based above data to calculate percentage error of each method depends on base population of study town to select the best method of population forecasting of future numbers of study area. The actual numbers of population in study area in 2018 is 22100 . 
Table 3. calculate the constant $\mathrm{K}_{1}, \mathrm{G}$ and $\mathrm{K}_{2}$

\begin{tabular}{|l|c|c|c|c|}
\hline Year & Population & AIM & GIM & IIM \\
\hline 2007 & 8906 & - & - & - \\
\hline 2014 & 12120 & 459.15 & 0.052 & - \\
\hline 2016 & 15684 & 1782 & 0.147 & 1323 \\
\hline total & & 2241.15 & 0.199 & 1323 \\
\hline average & & 1121 & 0.0995 & 1323 \\
\hline
\end{tabular}

Sample calculation $\quad \mathrm{k}=1121 \quad \mathrm{G}=0.0995 \quad \mathrm{~K} 2=1323$

Arithmetic increasing method $(\mathrm{AIM})=\frac{\mathrm{P} 2014-\mathrm{P} 2007}{2014-2007}=\frac{12120-8906}{7}=459.14$

Geometric increasing method $(\mathrm{GIM})=\frac{\text { Arithmetic increasing }}{\mathrm{P} 2007}=\frac{459.14}{8906}=0.052$

Incremental increasing method $(\mathrm{IIM})=\left(1^{\text {st }}\right.$ arithmetic $-2^{\text {nd }}$ arithmetic $)$ increasing

$$
=1782-459.14=1322.86=1323
$$

Calculate the numbers of population at 2018 by using arithmetic increasing method, geometric increasing method, incremental increasing method and exponential growth rate methods.

* Arithmetic increasing method of $2018=\mathrm{p}_{2016}+\mathrm{nk}$, where $\mathrm{p}_{2016}=15684$

$$
\begin{aligned}
& \mathrm{n}=2018-2016=2 \\
& \mathrm{k}=1121 \\
& \mathrm{P}_{2081}=15684+2 * 1121=17926
\end{aligned}
$$

* Geometric increasing method of $2018=\mathrm{P}_{2016} *(1+G)^{n}$, where $\mathrm{G}=0.0995, \mathrm{n}=2$

$$
\mathrm{P}_{2018}=15684 *(1+0.0995)^{2}=18961
$$

* Incremental increasing method of $2018=\mathrm{P} 2016+\mathrm{n}(\mathrm{k} 1+\mathrm{k} 2)$, where $\mathrm{k} 1=1121$ and $\mathrm{k} 2=1323$

$$
\mathrm{P}_{2018}=15684+2(1121+1323)=18454
$$

* Exponential growth rate method of $2018=\mathrm{P}_{2016} * e^{n r}$ where $\mathrm{n}=2$ and $\mathrm{r}=4.5 \%=0.045$

$$
\mathrm{P} 2018=15684 * e^{2 * 0.045}=17161
$$

Table 4: percentage error calculation by using four methods of forecasting

\begin{tabular}{|l|c|c|c|c|}
\hline Year & AIM & GIM & IIM & Exponential method \\
\hline 2018 (actual) & 22100 & 22100 & 22100 & 22100 \\
\hline 2018 (calculated) & 17926 & 18961 & 18454 & 17161 \\
\hline \% Error & 0.189 & 0.142 & 0.165 & 0.224 \\
\hline
\end{tabular}

Percentage Error $=\frac{\text { Actual population of 2018-calculated population of } 2018}{\text { Actal }}$

Percentage error of AIM $=\frac{22100-17926}{22100}=0.189$

Percentage error of GIM $=\frac{22100-18961}{22100}=0.142$

Percentage error of IIM $=\frac{22100-18454}{22100}=0.165$

Percentage error of Exponential method $=\frac{22100-17161}{22100}=0.224$

Therefore, the best methods of future population forecasting of study area for next 20 years is Geometric increasing method, because the value of percentage error is minimum than other three methods which is 0.142 .

Forecast the future population of study town by using Geometric increasing methods for 20 years of design periods (2022 -2042)

$\mathrm{P}_{\mathrm{n}}=\mathrm{P}_{\mathrm{o}} *(1+\mathrm{G})^{n r} \quad$ where $\mathrm{Pn}=$ numbers of future population

$\mathrm{Po}=$ present population of town $=22100$

$\mathrm{n}=$ numbers of year $=20$

$\mathrm{r}=$ population growth rate

Table 5: Summary of projected population of study town

\begin{tabular}{|l|l|l|l|l|l|}
\hline Year & 2022 & 2027 & 2032 & 2037 & 2042 \\
\hline Growth rate & $4 \%$ & $3.80 \%$ & $3.60 \%$ & $3.50 \%$ & $3.35 \%$ \\
\hline Projected Population & 25854 & 31154 & 37181 & 44160 & 45640 \\
\hline
\end{tabular}

\section{Sample calculation}

P2022 $=$ P2018 * $(1+G)^{\text {n }}, \quad$ where P2018 $=22100$

$$
\mathrm{G}=4 \%=0.04
$$$$
\mathrm{N}=4
$$

$\mathrm{P} 2022=22100 *(1+0.04)^{4}=25853.87=25854$

The total projected population of the town starting design period (2022) and end of design period (2042) are 25854 and 45640 respectively. The numbers of the study town are increase rapidly without any gap through the year. This indicates to needed more amounts of daily water consumption to meet different domestic activities every day throughout the year (William et al., 2015). Because the existing water supply does not much with numbers of 
current population of the study area, addition to this more people inter into study town from different sub-urban and rural area to find better jobs, better living standard, education, health services, and different infrastructures because this town is capital town of Fegita Lekoma Worda in Awi zone.

\section{Water Demand Assessment}

Water demand assessment is assessing all types of water required for the given town (Schleich and Hillenbrand, 2009). The major types of water demand or consumption for study town is domestic demand, non-domestic demand, fire demand and unaccounted water losses (Haziq and Panezai, 2017). These demands are calculated depends on standards of MoWR design guide lines and regional guidelines of the study area.

\subsection{Domestic Water Demand}

Domestic water demand is amounts of water required for different house activities, such as drinking, cooking, bathing, shower, toilet, etc (Arturo et al., 2017). These demands depend on different factors, examples climatic condition, economic levels of communities and social life (Admasie and Debebe, 2016). Totally domestic water demand can be categories into three mode of services. These are: - House connected, Yard connected, Public fountain and None connected (Misgana, 2015). Projecting domestic water demands of Addis Kidam town must be follow the following procedures. Population percentage distribution by mode of service, Establishment of per capital demand by purpose for each mode of service, Projection of consumption by mode of service, Adjustment due to climate and socio-economic condition and Projection of domestic water.

\subsubsection{Per capital domestic water demand}

Per capital water demand is various from town to town due to different factors (Hussien et al., 2016). These are size of town, numbers of population, types of water supply, quantity and quality of water sources, system of sanitation, climatic condition of area, socioeconomic condition and water pressure in distribution system of town (Feleke et al., 2018). Composition of per capital demand is given below table.

Table 6: Composition of per capital domestic water demand in year $2016(\mathrm{l} / \mathrm{c} / \mathrm{d})$

\begin{tabular}{|l|c|c|c|}
\hline Activity & $\mathrm{HC}(\mathrm{l} / \mathrm{c} / \mathrm{d})$ & $\mathrm{YC}(\mathrm{l} / \mathrm{c} / \mathrm{d})$ & $\mathrm{PF}(\mathrm{l} / \mathrm{c} / \mathrm{d})$ \\
\hline Drinking & 2.5 & 2.5 & 2.5 \\
\hline Cooking & 7.5 & 5.5 & 4.5 \\
\hline Ablution & 17 & 12 & 7 \\
\hline Washing Dish & 5 & 4 & 4 \\
\hline Laundry & 15 & 8 & 7 \\
\hline House Cleaning & 7 & 3 & 2 \\
\hline Bath and Shower & 20 & 4 & 2 \\
\hline Toilet & 6 & 1 & 1 \\
\hline Total & 80 & 40 & 30 \\
\hline
\end{tabular}

Source: - ministry of water resources

To estimate the future water demands of each types of dome of services is by using population growth rates of study area and per capital demands of each activity. According to water Works Design and Supervision Enterprise (WWDSE) had adopted the following growth rates.

Growth rate 2020-2025 up to $2025-2030$ is $\mathrm{HC}=2 \%, \mathrm{YC}=2 \%, \mathrm{PF}=1 \%$

Growth $2030-2035$ up to $2035-2042$ is $\mathrm{HC}=2.5 \%, \mathrm{YC}=1.8 \%, \mathrm{PF}=.9 \%$

Table 7: the domestic water demands of each mode service

\begin{tabular}{|l|l|l|l|l|l|l|l|l|l|l|l|l|l|l|l|l|}
\hline Year & \multicolumn{1}{|l}{2022} & \multicolumn{2}{l}{2027} & \multicolumn{2}{l|}{2032} & \multicolumn{3}{l|}{2042} \\
\hline Activity & HC & YC & PF & HC & YC & PF & HC & YC & PF & HC & YC & PF & HC & YC & PF \\
\hline Drinking & 2.815 & 2.8 & 2.7 & 3.3 & 3.04 & 2.8 & 3.7 & 3.33 & 2.9 & 4.2 & 3.64 & 3.02 & 4.75 & 3.98 & 3.16 \\
\hline Cooking & 8.45 & 6.2 & 4.8 & 9.8 & 6.69 & 5 & 11 & 7.32 & 5.2 & 13 & 8 & 5.43 & 14.3 & 8.75 & 5.68 \\
\hline Ablution & 19.14 & 14 & 7.4 & 22 & 14.6 & 7.7 & 25 & 16 & 8.1 & 29 & 17.5 & 8.45 & 32.3 & 19.1 & 8.84 \\
\hline Washing Dishes & 5.63 & 4.5 & 4.3 & 6.6 & 4.87 & 4.4 & 7.4 & 5.32 & 4.6 & 8.4 & 5.82 & 4.83 & 9.5 & 6.36 & 5.05 \\
\hline Laundry & 16.89 & 9 & 7.4 & 20 & 9.73 & 7.7 & 22 & 10.6 & 8.1 & 25 & 11.6 & 8.45 & 28.5 & 12.7 & 8.84 \\
\hline House Cleaning & 7.88 & 3.4 & 2.1 & 9.2 & 3.65 & 2.2 & 10 & 3.99 & 2.3 & 12 & 4.36 & 2.41 & 13.3 & 4.77 & 2.52 \\
\hline Shower & 22.52 & 4.5 & 2.1 & 26 & 4.87 & 2.2 & 30 & 5.32 & 2.3 & 34 & 5.82 & 2.41 & 38 & 6.36 & 2.52 \\
\hline Toilet & 6.67 & 1.1 & 1.1 & 7.9 & 1.22 & 1.1 & 8.9 & 1.33 & 1.2 & 10 & 1.45 & 1.21 & 11.4 & 1.59 & 1.26 \\
\hline Total & 90.09 & 45 & 32 & 105 & 48.7 & 33 & 119 & 53.2 & 35 & 134 & 58.2 & 36.2 & 152 & 63.9 & 37.9 \\
\hline
\end{tabular}

\section{Sample calculation for year 2022}

Activity type: drinking in $\mathrm{HC}, \mathrm{HC}_{2022}=\mathrm{HC}_{2016} *(1+\mathrm{G})^{\mathrm{n}}=2.5 *(1+0.02)^{6}=2.815$

Activity type: cooking in $\mathrm{YC}, \mathrm{YC}_{2022}=\mathrm{YC}_{2016} *(1+\mathrm{G})^{\mathrm{n}}=5.5^{*}(1+0.02)^{6}=6.19$

Activity type: cooking in $\mathrm{PF}, \mathrm{PF}_{2022}=\mathrm{PF}_{2016} *(1+\mathrm{G})^{\mathrm{n}}=4.5^{*}(1+0.01)^{6}=4.78$ 
Table 8: the percentage of population by mode of service level as follow

\begin{tabular}{|l|c|c|c|c|c|}
\hline \multirow{2}{*}{$\begin{array}{c}\text { mode of } \\
\text { service }\end{array}$} & \multicolumn{5}{|c|}{ Year } \\
\cline { 2 - 6 } & 2010 & 2015 & 2020 & 2025 & 2030 \\
\hline HC & $3.30 \%$ & $3.80 \%$ & $4.30 \%$ & $4.80 \%$ & $5.50 \%$ \\
\hline YC & $22.20 \%$ & $25.10 \%$ & $28.40 \%$ & $32.20 \%$ & $36.50 \%$ \\
\hline PF & $50.30 \%$ & $57 \%$ & $61.30 \%$ & $59 \%$ & $56 \%$ \\
\hline NC & $24.20 \%$ & $14.10 \%$ & $6 \%$ & $4 \%$ & $2 \%$ \\
\hline
\end{tabular}

Source: - Ministry of water sources

Table 9: the percentage of population projection by mode of service in study area

\begin{tabular}{|c|c|c|c|c|}
\hline \multirow{2}{*}{ Year } & \multicolumn{4}{|c|}{ Mode of service } \\
\cline { 2 - 5 } & HC & YC & PF & NC \\
\hline 2022 & $4.30 \%$ & $32.20 \%$ & $59 \%$ & $4 \%$ \\
\hline 2027 & $4.80 \%$ & $36.50 \%$ & $56 \%$ & $2 \%$ \\
\hline 2032 & $6.20 \%$ & $40.80 \%$ & $53 \%$ & 0 \\
\hline 2037 & $6.90 \%$ & $45.10 \%$ & $48 \%$ & 0 \\
\hline 2042 & $7.60 \%$ & $49.40 \%$ & $43 \%$ & 0 \\
\hline
\end{tabular}

Source: - Ministry of water resources of mode of services

\subsubsection{Population projected by each mode of service}

Population projected by each mode of service is depends on the total projection of town population and per-capital water demands of each mode of services of the study town, that means

Projected population $=$ percentage of population by mode of service* total number of populations

Table 10: projected population by mode of service

\begin{tabular}{|c|c|c|c|c|}
\hline Year & Mode of Service & Total Population & Percentage of Population & Projected Population \\
\hline \multirow{4}{*}{2022} & $\mathrm{HC}$ & 25854 & $4.30 \%$ & 1112 \\
\hline & $\mathrm{YC}$ & 25854 & $32.20 \%$ & 8354 \\
\hline & $\mathrm{PF}$ & 25854 & $59 \%$ & 15254 \\
\hline & $\mathrm{NC}$ & 25854 & $4 \%$ & 1034 \\
\hline \multirow{4}{*}{2027} & $\mathrm{HC}$ & 31154 & $4.80 \%$ & 1495 \\
\hline & $\mathrm{YC}$ & 31154 & $36.50 \%$ & 11589 \\
\hline & $\mathrm{PF}$ & 31154 & $56 \%$ & 17446 \\
\hline & $\mathrm{NC}$ & 31154 & $2 \%$ & 623 \\
\hline \multirow{3}{*}{2032} & $\mathrm{HC}$ & 37181 & $6.20 \%$ & 2305 \\
\hline & $\mathrm{YC}$ & 37181 & $40.80 \%$ & 15170 \\
\hline & $\mathrm{PF}$ & 37181 & $53 \%$ & 19706 \\
\hline \multirow{3}{*}{2037} & $\mathrm{HC}$ & 44160 & $6.90 \%$ & 3047 \\
\hline & $\mathrm{YC}$ & 44160 & $45.10 \%$ & 19916 \\
\hline & $\mathrm{PF}$ & 44160 & $48 \%$ & 21197 \\
\hline \multirow{3}{*}{2042} & $\mathrm{HC}$ & 45640 & $7.60 \%$ & 3469 \\
\hline & $\mathrm{YC}$ & 45640 & $49.40 \%$ & 22546 \\
\hline & $\mathrm{PF}$ & 45640 & $4.00 \%$ & 1826 \\
\hline
\end{tabular}

Sample calculation of above table for year 2022

Total population $=25854$

Population distribution by mode of service, $\mathrm{HC}=4.3 \%, \mathrm{YC}=32.2 \%, \mathrm{PF}=59 \%$ and $4 \%$.

Projected population $=$ percentage distribution of each mode of service $*$ total population
$\mathrm{HC}=4.3 \% * 25854=1112$
$\mathrm{PF}=59 * 25854=15254$
$\mathrm{YC}=32.2 \% * 25854=8354$
$\mathrm{NC}=4 \% * 25854=1034$

\subsubsection{Projected daily average domestic demand}

Projected average daily domestic demand (ADDD) is production of projected population of each mode service and projected per-capital water demand by mode service of study town (Kassa, 2017).

Projected ADDD $(1 / \mathrm{d})=$ projected population*projected per capital water demand 
Table 11: projected daily average domestic demand

\begin{tabular}{|c|c|c|c|c|}
\hline Year & $\begin{array}{l}\text { mode of } \\
\text { service }\end{array}$ & $\begin{array}{l}\text { projected } \\
\text { population }\end{array}$ & $\begin{array}{l}\text { projected per capital water } \\
\text { demand }\end{array}$ & $\begin{array}{l}\text { projected domestic } \\
\text { demand }\end{array}$ \\
\hline \multirow{4}{*}{2022} & $\mathrm{HC}$ & 25854 & $\begin{array}{r}90.09 \\
\end{array}$ & 2329187 \\
\hline & $\mathrm{YC}$ & 25854 & 45 & 1163430 \\
\hline & $\mathrm{PF}$ & 25854 & 32 & 827328 \\
\hline & \multicolumn{3}{|c|}{ Total per capital domestic demand } & 4319945 \\
\hline \multirow{4}{*}{2027} & $\mathrm{HC}$ & 31154 & 105 & 3271170 \\
\hline & $\mathrm{YC}$ & 31154 & 48.7 & 1517200 \\
\hline & $\mathrm{PF}$ & 31154 & 33 & 1028082 \\
\hline & \multicolumn{3}{|c|}{ Total per capital domestic demand } & 5816452 \\
\hline \multirow{4}{*}{2032} & $\mathrm{HC}$ & 37181 & 119 & 4424539 \\
\hline & $\mathrm{YC}$ & 37181 & 53.2 & 1978029 \\
\hline & $\mathrm{PF}$ & 37181 & 35 & 1301335 \\
\hline & \multicolumn{3}{|c|}{ Total per capital domestic demand } & 7703903 \\
\hline \multirow{4}{*}{2037} & $\mathrm{HC}$ & 44160 & 134 & 5917440 \\
\hline & $\mathrm{YC}$ & 44160 & 58.2 & 2570112 \\
\hline & $\mathrm{PF}$ & 44160 & 36.2 & 1598592 \\
\hline & \multicolumn{3}{|c|}{ Total per capital domestic demand } & 10086144 \\
\hline \multirow{4}{*}{2042} & $\mathrm{HC}$ & 45640 & 152 & 6937280 \\
\hline & $\mathrm{YC}$ & 45640 & 63.9 & 2916396 \\
\hline & $\mathrm{PF}$ & 45640 & 37.9 & 1729756 \\
\hline & \multicolumn{3}{|c|}{ Total per capital domestic demand } & 11583432 \\
\hline \multicolumn{4}{|c|}{ Total domestic demand $(1 / \mathrm{d})$} & 39509876 \\
\hline \multicolumn{4}{|c|}{ Total domestic demand $\mathrm{m} 3 / \mathrm{d}$ ) } & 39509.88 \\
\hline
\end{tabular}

\subsubsection{Factors affecting the rate domestic water demand}

There are various factor affecting rate of water demand (Asgedom, 2014). These are climatic condition, cost of water, economic status of consumers, pressure in distribution system, quality and quantity of water, water supply and sanitation system and numbers of commercial area.

Climatic condition: -climate of this area is vary from season to season, due to this reason most of time very hot. During this time more amounts of water is required for all persons.

Cost of water: -cost of water is very cost during construction and after construction due to this reason most of communities cannot use piped water because more people are very poor.

Economic status of consumers: -most of living population are very poor, because this town are developing town and also country is developing country, due to this reason most people are not use house connected and yard connected mode of service but to most of town community public fountain system.

Quality and quantity of water: -there is not good quality and quantity water sources, such as surface and ground water total, this affects both economy and health status of communities.

Generally, the study town is affected by different factor natural and artificial activities throughout the year. Due to this reason most children and women lost time to find daily domestic water fare from their home every day, these affects their education, job and production of the individual person and total town as well as the country (Gelame, 2014).

\subsection{Adjusted Domestic Water Demand}

Projected daily average domestic water demand is adjusted by climatic condition and socio-economic conditions of the study town (Singh and Turkiya, 2013).

\subsubsection{Adjusted due to socio-economic factor}

Socio economic factor is the major factor for one town to design water supply systems, then this factor given below table.

Table 12: socio economic factor

\begin{tabular}{|l|l|c|}
\hline Group & Description & Adjustment factor \\
\hline A & $\begin{array}{l}\text { Town with high living and very high } \\
\text { potential development }\end{array}$ & 1.1 \\
\hline B & Town with high potential and lower living standard & 1.05 \\
\hline C & Town under normal Ethiopian condition & 1 \\
\hline D & Advanced rural town & 1.09 \\
\hline
\end{tabular}

Source: -National water supply and sanitary master plan

The socio-economic factor of study town is selected to be group $\mathrm{C}$, with factor 1 as the town has under normal 
Ethiopia condition.

\subsubsection{Adjusted due to climatic effect}

The Climate of project area has an impact on quantities of water consumptions. To account for changes of average per capital domestic demand, the water demand is multiplied by climatic factors recommended for target area.

Table 13: climatic factor

\begin{tabular}{|c|c|c|}
\hline Group & Mean Annual Precipitation & Factor \\
\hline A & 600 or less & 1.1 \\
\hline B & $601-900$ & 1.0 \\
\hline C & 901 or more & 0.9 \\
\hline
\end{tabular}

Source: Cost Effective Design Guide line

As per Fagita Lekoma Woreda Agricultural office data, the project area has precipitation ranging from $1,500 \mathrm{~mm}$ to $2,500 \mathrm{~mm}$ with mean annual rainfall of $2,000 \mathrm{~mm}$. Therefore, it is categorized in group $\mathrm{C}$, then value is 0.9 .

Therefore, adjusted daily average domestic demand is,

Adjusted daily average DD = daily average DD *Socio-economic factor*climatic factor

Table 14: adjusted domestic water demands of study town

\begin{tabular}{|c|c|c|c|c|c|}
\hline Year & $\begin{array}{l}\text { Total per capital domestic } \\
\text { demand (PDD)(L/D) }\end{array}$ & $\begin{array}{l}\text { Socio } \\
\text { factor }\end{array}$ & $\begin{array}{l}\text { Climatic } \\
\text { factor }\end{array}$ & $\begin{array}{l}\text { Adjusted domestic } \\
\text { demand(1/d) }\end{array}$ & $\begin{array}{l}\text { Adjusted domestic } \\
\text { demand (m3/d) }\end{array}$ \\
\hline 2022 & 4319945 & 1 & 0.9 & 3887950.5 & 3887.95 \\
\hline 2027 & 5816452 & 1 & 0.9 & 5234806.8 & 5234.81 \\
\hline 2032 & 7703903 & 1 & 0.9 & 6933512.7 & 6933.51 \\
\hline 2037 & 10086144 & 1 & 0.9 & 9077529.6 & 9077.53 \\
\hline 2042 & 11583432 & 1 & 0.9 & 10425088.8 & 10425.1 \\
\hline
\end{tabular}

Total domestic water demands of first phase is $6933.51 \mathrm{~m} 3 / \mathrm{d}$ and second phase are $10425.1 \mathrm{~m} 3 / \mathrm{d}$. This indicates amounts of water required for domestic purpose is rapidly increasing time to time. The numbers of population in study area increase gradually throughout the year without any gap.

\subsection{Non-Domestic Water Demand}

Non-domestic water demand is amounts of water demand required out of domestic water demand, which means industrial demand, commercial and institutional demand, public demand, fire demand, and unaccounted water loss demand (Rathnayaka et al., 2016).

Industrial demand: -is used for different types of industry, especially for small industries like, mining industry, small scale farming, soft drinking factory, food processing factory, metal factory, paper factory and etc. But large industry is not used water demand from town water supply system, because they are required high amounts of water demands, then it use its own sources of water separately. In this town there is not large industry due to this reason assumed $5 \%$ of total domestic demand is enough for all industries, which existing at current time.

Commercial and institutional demand: - is used to for different commercial and institutional area in study town, these areas are like hotel, restaurant and bars, shop centre, super markets, metal work, wood work, all consumer profit-based establishments required large volumes of water demand for their business need continuous supply and also governmental and non-governmental offices which live in study area. For this study amounts of water demand of commercial and institutional is assumed to be about $10 \%$ of the total domestic daily water demand.

Public demand: - is types of water demand, which use different public area of study town, like school, hospitals, health centres, churches, mosques, meeting hall, bus station, public offices, and public baths. These types of customers are non-profit institutions, which are basic for all community, due to this reason amounts of water required for public demand is assumed to be amount $15 \%$ of total daily domestic water demands of study town.

Fire demand: - is types of water demand which is used to fighting fire in study area. But at presents time Addis Kidam town has not any types firefighting and municipal services for firefighting as consumption standard or trends. Normally, firefighting demand is the most important for developing and developed towns and city to fight sudden fire in town or city, Due to this reason to calculate future fire demands of study area by using American insurance association formulas because the numbers of population is not big numbers, because developing town.

$$
Q=4637 \sqrt{P}(1-0.01 \sqrt{P})
$$

Where $\mathrm{Q}=$ amount of water required, $\mathrm{P}=$ population in thousands, the values of $\mathrm{P}$ is two depends on phase of project design period, that means for first phase $\mathrm{P}=37.181$ and second phase $\mathrm{P}=45.64$.

The first phase fire demand starting from 2022 up to 2032, if $\mathrm{P}=37.181$

$\mathrm{Q}=4637 * \sqrt{37.181}(1-0.01 \sqrt{37.181})=26550.6 \mathrm{~L} / \mathrm{hr}=637.21 \mathrm{~m} 3 / \mathrm{d}$

The second phase fire demand is starting from 2032 up to 2042 , if $\mathrm{P}=45.64$

$\mathrm{Q}=4637 * \sqrt{45.64}(1-0.01 \sqrt{45.64})=29210.03 \mathrm{~L} / \mathrm{hr}=701.04 \mathrm{~m} 3 / \mathrm{d}$

Unaccounted water losses and wastage: - this types water demand is required for extravagance water demand 
by water losses and wastage by different unwanted activities in one town or city throughout design periods of project in study area. These water demand does not reach directly or indirectly to consumer, due to the following reasons, such as water losses due to defective pipes and valves joints, cracked and broken pipes, faulty valves and fittings. Water losses due to, consumers keep open their taps of public taps even when they are not using the water and allow the continuous wastage of water and losses due to unauthorized and illegal connections (Jeandron et al., 2015). Generally unaccounted water losses and wastage demand is assumed to be $20 \%-30 \%$ of total quantity of water demand, but for Addis Kidam town is $20 \%$ of total quantity of water is made to compensate for losses, thefts and wastage of water.

\subsection{Average Daily Water Demand}

Average daily water demand (ADD) is summation of domestic water demand, non-domestic water demand, fire demand and unaccounted water losses and wastages of water per day throughout design periods of this projects (Rumalongo et al., 2017).

$$
\mathrm{ADD}=\mathrm{DD}+\mathrm{NDD}+\mathrm{FD}+\mathrm{UND}
$$

\subsection{Maximum Daily Demand}

The maximum daily water demand is the highest water demand of any one of $24 \mathrm{hr}$ period over any specific year in study area throughout design periods. Maximum daily demand is used to design different water supply components, such as to determine quantities of water sources (surface or groundwater), determine capacity of collection chamber and booster station, raising main pipes starting from sources of water up to service reservoir, capacity of all treatment plants if sources water is surface, capacity of pump and intake structure and capacity of service reservoir of study town (Romano et al., 2016). Due to this reason maximum daily demand have its own factors to calculate maximum day demand of the study town depends on numbers of town population. Therefore, general formulas of MDD is as follows,

$$
\begin{array}{rl}
\mathrm{MDD}=\mathrm{ADD} & \mathrm{MDF}, \text { where } \mathrm{MDD} \\
\mathrm{ADD} & =\text { Maximum Daily Demand } \\
\mathrm{MDF} & =\text { Maximum Daily Factor }
\end{array}
$$

\subsection{Peak Hourly Demand}

Peak hourly water demand is highest demand any one of one hour in specific 24hours. The PHD is represents variation in the water demand resulting from the behavioral pattern of the population. Generally, there are two ways. One in morning and second in after noon. PHD have its own factor depends on density of population presents, which is Peak Hourly Factors (PHF). Peak hourly demand is used to design distribution system of water supply schemes of study town.

$$
\begin{aligned}
& \mathrm{PHD}=\mathrm{ADD} * \mathrm{PHF}, \text { where } \mathrm{PHD}=\text { Peak Hourly Demand } \\
& \mathrm{ADD}=\text { Average Daily Demand } \\
& \mathrm{PHF}=\text { Peak Hourly Factor }
\end{aligned}
$$

Table 15: the factors of maximum daily demand and peak hourly demand

\begin{tabular}{|l|c|c|}
\hline Population & MDF & PHF \\
\hline 0 to 20,000 & 1.3 & 2 \\
\hline 20,001 to 50,000 & 1.25 & 1.9 \\
\hline 50001 and above & 1.2 & 1.7 \\
\hline
\end{tabular}

If numbers of study town population at end of design period is 45640, then this number is ranges of 20001 to 50000 , therefore the factors of maximum daily demand and peak hourly demand is 1.25 and 1.9 respectively. As total calculation of water demand assessments of study town is shown below table 16 . 
Table 16: summarized water demand assessments of study area

\begin{tabular}{|c|c|c|c|c|c|c|}
\hline Year & Unit & 2022 & 2027 & 2032 & 2037 & 2042 \\
\hline Population & No & 25854 & 31154 & 37181 & 44160 & 45640 \\
\hline Domestic demand (DD) & $\mathrm{m}^{3} / \mathrm{d}$ & 3887.81 & 5234.81 & 6933.51 & 9077.53 & 10425.1 \\
\hline Industrial Demand factor & $\%$ & $5 \%$ & $5 \%$ & $5 \%$ & $5 \%$ & $5 \%$ \\
\hline Industrial Demand (ID) & $\mathrm{m}^{3} / \mathrm{d}$ & 194.3905 & 261.7405 & 346.6755 & 453.8765 & 521.255 \\
\hline $\begin{array}{l}\text { commercial \& institutional } \\
\text { Demand factor }\end{array}$ & $\%$ & $10 \%$ & $10 \%$ & $10 \%$ & $10 \%$ & $10 \%$ \\
\hline $\begin{array}{l}\text { commercial \& institutional } \\
\text { Demand (CID) }\end{array}$ & $\mathrm{m}^{3} / \mathrm{d}$ & 388.781 & 523.481 & 693.351 & 907.753 & 1042.51 \\
\hline Public Demand Factor & $\%$ & $15 \%$ & $15 \%$ & $15 \%$ & $15 \%$ & $15 \%$ \\
\hline Public Demand (PD) & $\mathrm{m}^{3} / \mathrm{d}$ & 583.1715 & 785.2215 & 1040.0265 & 1361.6295 & 1563.765 \\
\hline Fire Demand (FD) & $\mathrm{m}^{3} / \mathrm{d}$ & 637.21 & 637.21 & 637.21 & 701.04 & 701.04 \\
\hline Unaccounted water factor & $\%$ & $20 \%$ & $20 \%$ & $20 \%$ & $20 \%$ & $20 \%$ \\
\hline $\begin{array}{l}\text { Unaccounted water } \\
\text { demand }\end{array}$ & $\mathrm{m}^{3} / \mathrm{d}$ & 777.562 & 1046.962 & 1386.702 & 1815.506 & 2085.02 \\
\hline \multirow{2}{*}{$\begin{array}{l}\text { Average Daily Demand } \\
\text { (ADD) }\end{array}$} & $\mathrm{m}^{3} / \mathrm{d}$ & 6468.925 & 8489.425 & 11037.475 & 14317.335 & 16338.69 \\
\hline & $1 / \mathrm{d}$ & 6468925 & 8489425 & 11037475 & 14317335 & 16338690 \\
\hline Maximum Daily factor & & 1.25 & 1.25 & 1.25 & 1.25 & 1.25 \\
\hline \multirow{2}{*}{$\begin{array}{l}\text { Maximum Daily Demand } \\
\text { (MDD) }\end{array}$} & $\mathrm{m}^{3} / \mathrm{d}$ & 8086.15625 & 10611.7813 & $\mathbf{1 3 7 9 6 . 8 4 3 8}$ & 17896.6688 & 20423.36 \\
\hline & $1 / \mathrm{d}$ & 8086156.25 & 10611781.3 & 13796843.8 & 17896668.8 & 20423363 \\
\hline Peak Hourly factor & & 1.9 & 1.9 & 1.9 & 1.9 & 1.9 \\
\hline \multirow{2}{*}{$\begin{array}{l}\text { Peak Hourly Demand } \\
\text { (PHD) }\end{array}$} & $\mathrm{m}^{3} / \mathrm{d}$ & 12290.9575 & 16129.9075 & 20971.2025 & 27202.9365 & 31043.51 \\
\hline & $1 / d$ & 12290957.5 & 16129907.5 & 20971202.5 & 27202936.5 & 31043511 \\
\hline
\end{tabular}

Sample calculation of above table is,

$\mathrm{ADD}=\mathrm{DD}+\mathrm{ID}+\mathrm{CID}+\mathrm{PD}+\mathrm{FD}+\mathrm{UND}$

$\mathrm{ADD}=3887.81+194.3905+388.781+583.1715+637.21+777.562=6468.925 \mathrm{~m}^{3} / \mathrm{d}$

$\mathrm{MDD}=\mathrm{ADD} * \mathrm{MDF}=6468.925 * 1.25=8086.15625 \mathrm{~m}^{3} / \mathrm{d}$

$\mathrm{PHD}=\mathrm{ADD} * \mathrm{PHF}=6468.925 * 1.9=12290.9575 \mathrm{~m}^{3} / \mathrm{d}$

From above table the first phase of maximum daily demand and peak hourly demand is $13796.8438 \mathrm{~m}^{3} / \mathrm{d}^{\text {and }}$ $20971.2025 \mathrm{~m}^{3} / \mathrm{d}$ respectively and the second phase of maximum daily demand and peak hourly demand is $20423.36 \mathrm{~m}^{3} / \mathrm{d}$ and $31043.51 \mathrm{~m}^{3} / \mathrm{d}$ respectively. As generally water demands of existing system is very less compare to with the current water demands of study town, this cause major problem on town communities' day to day activities in said house and outside their house.

\section{Water Source}

Adequate amounts of water sources are requirement for study town population to fitful their daily needs up to end design periods of this study (Aynalem, 2015). Due to this reason finding adequate quantity and quality of water sources depends on basic criteria's of select sources of water, such as location, quantity, quality and cost of water during construction and after construction for operation and maintenance cost are the basic need for this town (Iraj and Rao, 2016). Because without adequate amounts of water there is not adequate amounts average daily demand, maximum daily and peak hourly demands of water for town. Due to these reasons the Water Supply Committee of the town, Water Supply service offices and other concerned bodies recommends the water source options for further investigations and the consultant team observed the sites accordingly. Therefore, Water sources for long term sustainable water supply system for study town is described below.

1. Bilti spring: Located near to Manguda Michael at around $\mathbf{1 3} \mathbf{~ k m}$ from the town down stream of Zimbri Mesk

2. Amesha Spring: refer below

3. Enchetab Spring: Located in Gafera kebele at around $4.5 \mathrm{~km}$ from the town

Considering these spring depends on quality, quantity, easy of spring capping structure, location of collection chamber, distance of the spring source and supplied area or town of study area (Marson, 2015), the Amesha and Enchetab spring is proposed for the first phase and for the second phase of water supply system. The proposed source of water supply "Amesha Spring" is located at Amesha shinkuri kebele with UTM location of N1221380.35, Easting, E-264469.78 and Elevation of $2476.72 \mathrm{~m}$ amsl.

The estimated yield of the Amesha spring and Enchetab spring is 17 1/s and $25 \mathrm{l} / \mathrm{s}$ respectively. Therefore, a spring collection and Capping structure are constructed at downstream of the recharge area to tap and collect the water potential at selected site is recommended.

The existing spring yield is $7.5 \mathrm{l} / \mathrm{s}$ and the escaped amount of water from existing spring capping structure is $4.01 / \mathrm{s}$, after additional capping structure work, are to be used in the new water supply system. Therefore, the total 
water source is $53.5 \mathrm{lit} / \mathrm{sec}$.

The required maximum daily demand of study town is $159.681 / \mathrm{s}$ and $236.38 \mathrm{l} / \mathrm{s}$ in the first phase 2032 and second phase of 2042 respectively. The existing water source is covers only $33.5 \%$ and $22.63 \%$ of total current and future maximum daily water demands of town communities of first and second phase respectively. This water source satisfies only one small population of study town. Hence, additional Water Source is required to meet these current and future demand of town and also find additional water source to meet first and second phase of maximum daily demands and peak hourly demand of the study town, which is $106.18 \mathrm{l} / \mathrm{s}$ and $183 \mathrm{l} / \mathrm{s}$ respectively throughout design period.

\subsection{Capacity of Raising Main}

Gravity raising main is designed to convey economically yield from spring capping structure to the collection chamber. The total length of the Gravity main line is $3,110 \mathrm{~m}$. The size of the economical gravity main line is calculated by using the empirical formula.

$$
\mathrm{D}=0.97 \sqrt{\mathrm{Q}} \text { to } 1.22 \sqrt{\mathrm{Q}} \text {, Where } \mathrm{Q}=\text { Yield of the spring }[17 \mathrm{l} / \mathrm{s}]
$$

$\mathrm{D}=$ Economical diameter in meters

Therefore, OD 160mm [ID $127.6 \mathrm{~mm}$ ] PN16 HDPE pipe is recommended and the flow velocity is recommended $0.6 \mathrm{~m} / \mathrm{s}$ to $2 \mathrm{~m} / \mathrm{s}$, then $1.5 \mathrm{~m} / \mathrm{s} \Rightarrow$ Safe for this project.

The spring is susceptible to flooding in the upstream direction. Therefore, retaining wall of length $30 \mathrm{~m}$, bottom width $0.9 \mathrm{~m}$ and top width $0.4 \mathrm{~m}$ is recommended.

\subsection{Capacity of Collection Chamber}

The collection chambers are proposed to: Collect water from spring capping structure, serve as night storage of the yield of the spring and Store Water for pumping to service reservoir. Considering the above facts, 75 minutes detention time is adopted calculate capacity of the collection chamber of the yield of the spring. The collection chamber is located at UTM location of N-1,222,971.43, E-266,483.69 and Elevation of 2,393.93m above mean sea level.

Capacity of collection chamber $=\mathrm{Q} *$ Detention time, where $\mathrm{Q}=$ Yield of the spring $[17 \mathrm{l} / \mathrm{s}]$

\subsection{Pressure Main Raising Line}

The pressure main raising line, from collection chamber to the service reservoir, is designed to convey economically the yield of the spring. The total length of spring up to service reservoir is $4,510 \mathrm{~m}$. The economical size or diameter of the pressure main raising line is calculated by using the empirical formula $\mathrm{D}=0.97 \sqrt{\mathrm{Q}}$ to $1.22 \sqrt{\mathrm{Q}}$, Where $\mathrm{Q}=$ Yield of the spring $[17 \mathrm{~L} / \mathrm{S}), \mathrm{D}=$ Economical diameter in meters

Therefore, OD180mm (ID 135.4) HDPE PN20 pipe is recommended. The velocity is $1.2 \mathrm{~m} / \mathrm{s}$, because to balance the pressure unsaid the pipe of flow and resist the pipe duration.

\subsection{Capacity of Service Reservoir}

The number and size of service reservoirs are often determined based on number and sizes of the defined pressure zones, topographic suitability, size of the area selected for reservoirs construction, availability of standard reservoir sizes and the volume of water which has to be stored for demand fluctuation purpose (Abdisa and Reddy, 2014). The size of service reservoir is often determined using different methods. The most appropriate and economical approach is to carry out a 24-hour supply and demand simulation and then produce the corresponding design mass curve. To produce such types of curves and generate design curves, it requires reliable historical data on hourly water demand variations of the town. Due to this reason to determine the capacity of service reservoir is by using analytical method and mass curve method depends on given data recorded in study town below table.

$$
\text { Table 17: the 24-hourly peak factors of the Addis Kidam town }
$$

\begin{tabular}{|l|c|c|c|c|c|c|c|c|c|c|c|c|}
\hline Time & 1 & 2 & 3 & 4 & 5 & 6 & 7 & 8 & 9 & 10 & 11 & 12 \\
\hline Hourly factor & 0.3 & 0.3 & 0.3 & 0.3 & 0.5 & 0.8 & 1 & 1.3 & 2 & 1.7 & 1.6 & 2 \\
\hline Time & 13 & 14 & 15 & 16 & 17 & 18 & 19 & 20 & 21 & 22 & 23 & 24 \\
\hline Hourly factor & 1.4 & 1.3 & 1.3 & 1.4 & 1.4 & 1.4 & 1 & 1.2 & 1 & 0.8 & 0.5 & 0.24 \\
\hline
\end{tabular}

Sources: feasibility study of the study town

Determination of capacity of service reservoir for first phase (2022-2032) year

Total maximum daily demand $=13796.844 \mathrm{~m} 3 / \mathrm{d}$ or $13796844 \mathrm{l} / \mathrm{d}$

Hourly demand of town $=\frac{13796844 \mathrm{l} / \mathrm{d}}{24}=574868.5 \mathrm{l} / \mathrm{d}$

Assume pumping hours $=18 \mathrm{hr}$

Pumping rate $=\frac{24 h r}{\text { pumping hour }(18 h r)}$ *hourly demand $(574868.5 \mathrm{l} / \mathrm{d})=766491.333 \mathrm{l} / \mathrm{d}$ 
Table 18: analytical calculation methods of capacity of service reservoir for first phase(liter)

\begin{tabular}{|c|c|c|c|c|c|c|c|}
\hline $\begin{array}{c}\text { Time(hr) } \\
1\end{array}$ & $\begin{array}{l}\text { Hourly } \\
\text { factor } 2\end{array}$ & $\begin{array}{l}\text { Hourly } \\
\text { supply } \\
3 \text { (liter) }\end{array}$ & $\begin{array}{c}\text { Hourly demand } \\
4=2 * 574869.5 \\
\text { (liter) }\end{array}$ & $\begin{array}{l}\text { Comm. } \\
\text { hourly } \\
\text { demand } \\
5 \text { (liter) }\end{array}$ & $\begin{array}{l}\text { Comm. } \\
\text { hourly } \\
\text { supply } \\
\text { 6(liter) }\end{array}$ & $\begin{array}{c}\text { Excess } \\
\text { demand } \\
7=5- \\
6 \text { (liter) }\end{array}$ & $\begin{array}{c}\text { Excess } \\
\text { supply } \\
8=6- \\
5 \text { (liter) }\end{array}$ \\
\hline 1 & 0.25 & 0 & 143717 & 143717 & 0 & 143717 & \\
\hline 2 & 0.3 & 0 & 172461 & 316178 & 0 & 316178 & \\
\hline 3 & 0.3 & 0 & 172461 & 488638 & 0 & 488638 & \\
\hline 4 & 0.3 & 766491.3 & 172461 & 661099 & 766491 & & 105393 \\
\hline 5 & 0.5 & 766491.3 & 287434 & 948533 & 1532983 & & 584450 \\
\hline 6 & 0.8 & 766491.3 & 459895 & 1408428 & 2299474 & & 891046 \\
\hline 7 & 1 & 766491.3 & 574869 & 1983296 & 3065965 & & 1082669 \\
\hline 8 & 1.3 & 766491.3 & 747329 & 2730625 & 3832457 & & 1101831 \\
\hline 9 & 2 & 766491.3 & 1149737 & 3880362 & 4598948 & & 718586 \\
\hline 10 & 1.7 & 766491.3 & 977276 & 4857639 & 5365439 & & 507800 \\
\hline 11 & 1.6 & 766491.3 & 919790 & 5777428 & 6131931 & & 354502 \\
\hline 12 & 2 & 766491.3 & 1149737 & 6927165 & 6898422 & 28743 & \\
\hline 13 & 1.3 & 0 & 747329 & 7674494 & 6898422 & 776073 & \\
\hline 14 & 1.3 & 0 & 747329 & 8421824 & 6898422 & 1523402 & \\
\hline 15 & 1.3 & 766491.3 & 747329 & 9169153 & 7664913 & 1504239 & \\
\hline 16 & 1.4 & 766491.3 & 804816 & 9973968 & 8431405 & 1542564 & \\
\hline 17 & 1.4 & 766491.3 & 804816 & 10778784 & 9197896 & 1580888 & \\
\hline 18 & 1.4 & 766491.3 & 804816 & 11583600 & 9964387 & 1619213 & \\
\hline 19 & 1 & 766491.3 & 574869 & 12158469 & 10730879 & 1427590 & \\
\hline 20 & 1.2 & 766491.3 & 689842 & 12848311 & 11497370 & 1350941 & \\
\hline 21 & 1 & 766491.3 & 574869 & 13423179 & 12263861 & 1159318 & \\
\hline 22 & 0.8 & 766491.3 & 459895 & 13883074 & 13030353 & 852722 & \\
\hline 23 & 0.5 & 766491.3 & 287434 & 14170509 & 13796844 & 373665 & \\
\hline 24 & 0.24 & 0 & 137968 & 14308477 & 13796844 & 511633 & 0 \\
\hline
\end{tabular}

Therefore, the maximum cumulative of excess demand $=1619213$ liter $=1619.213 \mathrm{~m}^{3}$

The maximum cumulative of excess supply $=1101831$ liter $=1101.831 \mathrm{~m}^{3}$

Then, Equalizing volume of service reservoir=Max. Cumulative excess (demand + supply)

Equalizing volume of service reservoir $=(1619.213+1101.831) \mathrm{m}^{3}=2721.044 \mathrm{~m}^{3}$

But the total volume of service reservoir $=($ Equalizing + Breakdown + Fire $)$ volume

Let as assumed breakdown storage of service reservoir as 2-3hr pumping rate, then take $3 \mathrm{hr}$

Break down storage of service reservoir $=3 \mathrm{hr} *$ pumping rate

$$
=3 \mathrm{hr} * 31.937 \mathrm{~m}^{3} / \mathrm{hr}=95.811 \mathrm{~m}^{3}
$$

Les as assumed fire storages of service reservoir as $2-51 / \mathrm{c} / \mathrm{d}$, then take $51 / \mathrm{c} / \mathrm{d}$

Fire storages of service reservoir $=51 / \mathrm{c} / \mathrm{d} *$ No of population

$$
=51 / \mathrm{c} / \mathrm{d} * 37181=185.905 \mathrm{~m}^{3}
$$

Therefore, total volumes of service reservoir (SR) for first phase is,

Total volume of $\mathrm{SR}=2721.044 \mathrm{~m}^{3}+95.811 \mathrm{~m}^{3}+185.905 \mathrm{~m}^{3}=3002.76 \mathrm{~m}^{3}$

Then provide $3000 \mathrm{~m}^{3}$ is safe for this phase.

For second phase (2032 - 2042) year

Total maximum daily demand $=20243.51 \mathrm{~m} 3 / \mathrm{d}$

Hourly demand of town $=\frac{20243.51 \mathrm{~m} 3 / \mathrm{d}}{24}=843.48 \mathrm{~m} 3 / \mathrm{d}$

Assume pumping hours $=20 \mathrm{hr}$

Pumping rate $=\frac{24 h r}{\text { pumping hour }(20 h r)} *$ hourly demand $(843.48 \mathrm{~m} 3 / \mathrm{d})=1012.176 \mathrm{~m} 3 / \mathrm{d}$ 
Table 19: analytical calculation methods of capacity of service reservoir for second phase $\left(\mathrm{m}^{3}\right)$

\begin{tabular}{|c|c|c|c|c|c|c|c|}
\hline Time(hr) 1 & $\begin{array}{l}\text { Hourly } \\
\text { factor } 2\end{array}$ & $\begin{array}{l}\text { Hourly } \\
\text { supply } 3 \\
\text { (m3) }\end{array}$ & $\begin{array}{l}\text { Hourly demand } \\
4=2 * 843.48 \mathrm{~m} 3\end{array}$ & $\begin{array}{l}\text { Comm. } \\
\text { hourly } \\
\text { demand } \\
5(\mathrm{~m} 3)\end{array}$ & $\begin{array}{l}\text { Comm. } \\
\text { hourly } \\
\text { supply } 6 \\
\text { (m3) }\end{array}$ & $\begin{array}{l}\text { Excess } \\
\text { demand } \\
7=5-6 \\
\text { (m3) }\end{array}$ & $\begin{array}{l}\text { Excess } \\
\text { supply } 8=6-5 \\
(\mathrm{~m} 3)\end{array}$ \\
\hline 1 & 0.25 & 0 & 211 & 211 & 0 & 211 & \\
\hline 2 & 0.3 & 0 & 253 & 464 & 0 & 464 & \\
\hline 3 & 0.3 & 1012 & 253 & 717 & 1012 & & \\
\hline 4 & 0.3 & 1012 & 253 & 970 & 2024 & & 1054 \\
\hline 5 & 0.5 & 1012 & 422 & 1392 & 3037 & & 1645 \\
\hline 6 & 0.8 & 1012 & 675 & 2067 & 4049 & & 1982 \\
\hline 7 & 1 & 1012 & 843 & 2910 & 5061 & & 2151 \\
\hline 8 & 1.3 & 1012 & 1097 & 4007 & 6073 & & 2067 \\
\hline 9 & 2 & 1012 & 1687 & 5693 & 7085 & & 1392 \\
\hline 10 & 1.7 & 1012 & 1434 & 7127 & 8097 & & 970 \\
\hline 11 & 1.6 & 1012 & 1350 & 8477 & 9110 & & 633 \\
\hline 12 & 2 & 1012 & 1687 & 10164 & 10122 & 42 & \\
\hline 13 & 1.3 & 0 & 1097 & 11260 & 10122 & 1139 & \\
\hline 14 & 1.3 & 0 & 1097 & 12357 & 10122 & 2235 & \\
\hline 15 & 1.3 & 1012 & 1097 & 13454 & 11134 & 2320 & \\
\hline 16 & 1.4 & 1012 & 1181 & 14634 & 12146 & 2488 & \\
\hline 17 & 1.4 & 1012 & 1181 & 15815 & 13158 & 2657 & \\
\hline 18 & 1.4 & 1012 & 1181 & 16996 & 14170 & 2826 & \\
\hline 19 & 1 & 1012 & 843 & 17840 & 15183 & 2657 & \\
\hline 20 & 1.2 & 1012 & 1012 & 18852 & 16195 & 2657 & \\
\hline 21 & 1 & 1012 & 843 & 19695 & 17207 & 2488 & \\
\hline 22 & 0.8 & 1012 & 675 & 20370 & 18219 & 2151 & \\
\hline 23 & 0.5 & 1012 & 422 & 20792 & 19231 & 1560 & \\
\hline 24 & 0.24 & 1012 & 202 & 20994 & 20244 & 751 & \\
\hline
\end{tabular}

Therefore, the maximum cumulative of excess demand $=2826 \mathrm{~m}^{3}$

The maximum cumulative of excess supply $=2151 \mathrm{~m}^{3}$

Then, Equalizing volume of service reservoir=Max. Cumulative excess (demand + supply)

Equalizing volume of service reservoir $=(2826+2151) \mathrm{m}^{3}=4977 \mathrm{~m}^{3}$

But the total volume of service reservoir $=($ Equalizing + Breakdown + Fire $)$ volume

Let as assumed breakdown storage of service reservoir as 2-3hr pumping rate, then take $3 \mathrm{hr}$

Break down storage of service reservoir $=3 \mathrm{hr} *$ pumping rate

$$
=3 \mathrm{hr} * 42.174 \mathrm{~m}^{3} / \mathrm{hr}=126.522 \mathrm{~m}^{3}
$$

Les as assumed fire storages of service reservoir as $2-51 / \mathrm{c} / \mathrm{d}$, then take $51 / \mathrm{c} / \mathrm{d}$

Fire storages of service reservoir $=51 / \mathrm{c} / \mathrm{d} *$ No of population

$$
=51 / \mathrm{c} / \mathrm{d} * 45640=228.2 \mathrm{~m}^{3}
$$

Therefore, total volumes of service reservoir (SR) for second phase is,

Total volume of $\mathrm{SR}=4977 \mathrm{~m}^{3}+126.522 \mathrm{~m}^{3}+228.2 \mathrm{~m}^{3}=5332 \mathrm{~m}^{3}=5350 \mathrm{~m}^{3}$

Then provide $5350 \mathrm{~m}^{3}$ is safe for this phase.

Totally to provide capacity of service reservoir for first and second phase is $300 \mathrm{~m}^{3}$ and $5350 \mathrm{~m}^{3}$ respectively up to end of design periods of study area to balance reservoir problems of current and future time in town.

\section{Conclusion}

Existing water sources and demand of study is not adequate quantity and safe quality for current numbers of town population, because the numbers of town population increasing rapidly without any gap throughout the year, but amounts of water demand is decreasing time to time throughout its design period starting period up to now.

The total projection of the town population in first and second phase is 37181 and 45640 respectively for 20 years design period by using geometric increasing methods. Projected water demand of town for first and second phase is $13796.84 \mathrm{~m} 3$ and $20423.36 \mathrm{~m} 3$ of maximum daily demand respectively and $20971 \mathrm{~m} 3$ and $31043.51 \mathrm{~m} 3 / \mathrm{d}$ of peak hourly demand respectively for current and future time up to end of design periods this town.

Existing water sources of the study town is $53.5 \mathrm{l} / \mathrm{s}$, which is not meet the current water demands of the town, the required maximum daily demand of study town is $159.681 / \mathrm{s}$ and $236.38 \mathrm{l} / \mathrm{s}$ in the first phase 2032 and second phase of 2042 respectively. The existing water source is covers only $33.5 \%$ and $22.63 \%$ of total current and future maximum daily water demands of town communities of first and second phase respectively. To provide additional 
water source to meet first and second phase of maximum daily demands and peak hourly demand of the study town, which is $106.18 \mathrm{l} / \mathrm{s}$ and $183 \mathrm{l} / \mathrm{s}$ respectively throughout design period. The capacity of service reservoir of first and second phase of study town is $3000 \mathrm{~m} 3$ and $5350 \mathrm{~m} 3$ respectively up to end design period.

Generally, to provide adequate amounts and safe water demand and water sources is the most important for study town to develop by social and economic aspects of the communities throughout their life.

\section{Ethical Statement}

Ethical statement of this paper is all participant authors have no any types of compliance to published this paper from Journal of Applied Water Science. All authors are happy to publish this article paper from applied water science journal because its publishing is open access and do not have to pay the article processing charge or free for publication charges. The funding of this article paper is funding information is not applicable or not funding is received before or after publication of this paper for all participant authors. Our interest will be to publish more research papers at current and for future time from this journal.

\section{References}

Abdisa, M., and Reddy, U. (2014). Assessment of potable water supply, in Awaday Town, Ethiopia. The international journal of social sciences, Vol.19. No. (1), pp.12-18.

Adane, M., Mengistie, B., Medhin, G., Kloos, H., and Mulat, W. (2017). Piped water supply intrruptions and acute diarrhea among under-five children in Addis Ababa slums, Ethiopia: matched case-control study. PLoS 1, 6(12), pp 23-26.

Adegbehin, A., Yusuf, Y., Anumonye, E., and Shehu, A. (2016). Problems of domestic water supply in dutsen kura gwari, chanchaga local government area of niger state, Nigeria. Journal of Geography, Environment and Earth Science International, ISSN: 2454-7352.

Admasie, A., and Debebe, A. (2016). Estimating Access to Drinking Water Supply, Sanitation, and Hygiene Facilities in Wolaita Sodo Town, Southern Ethiopia, in Reference to National Coverage. Journal of Environmental and Public Health, Volume 9, Issue 12, p 9-13.

Akkaraboyina, M., and Adem, A. (2018). An assessment study of the challenges of urban water supply in case of galkayo town, puntland, somalia., Volume 5, Issue 4, JETIR, www.jetir.org (ISSN-2349-5162), PP.14-28.

Alua, O., Kamshat, T., Peder, H., Marat, K., and Raushan, D. (2019). Water Supply Challenges in Rural Areas: A Case Study from Central Kazakhstan. International Journal of Environmental research and Publich health, pp 3-11.

Arturo, O., Clara, R., Marco, A., Ramos, C., and Fernando, H. (2017). Determinants of domestic water consumption in Hermosillo, Sonora, Mexico. V.6, Issue 1, PP 48-53, www.ioserjournals.org.

Asgedom, D. (2014). Assessing causes and challenges of urban water supply: the case of Mekelle City. Master thesis, Int J Sci Res 3(7):1922-1928.

Aynalem, K. (2015). Access to water supply in urban poor households, The case of slums in Addis Ababa, Ethiopia, Master of Science Thesis, P 35-58.

Dagnew, E., Kassa, A., and Awuke, A. (2017). Challenges, Opportunities and Management Practice of Pig Production in Debre Markos Town, East Gojjam Zone in Amahra Regional State, Ethiopia, Emebet et al., Poult Fish Wildl Sci, V.5: P.24-28.

Emenike, C., Tenebe, I., Omole, D., Ngene, B., and Oniemayin, B. (2017). Accessing safe drinking water in subSaharan Africa: issues and challenges in South-West Nigeria. Sustain Cities Soc. 30:263-272.

Ermias, M. (2016). Assessment of Urban Water Supply and Sanitation: The Case of Bedesa Town, Damot Woyde Woreda of Wolaita Zone, Southern Ethiopia. ISSN 2224-3208 (Paper) ISSN 2225-093X (Online) Vol.6, No.5, pp 8-19.

Farah, K., and Yonis, T. (2015). Challenges of sustaining water supply for rapidly growing post war city- a case of Hargeisa city, 38th WEDC, International conference Lough borough University, UK, pp 7-15.

Feleke, H., Girmay, M., Helmut, K., and Daniel, A. (2018). Household stored drinking water quality among households of under-five children with and without acute diarrhea in towns of Wegera District, in North Gondar, Northwest Ethiopia. Volume 8, Issue.3, p.258-302.

Gelame, A. (2014). Assessment of urban domestic water supply: the case of Gimbichu town in soro woreda, hadiya zone, SNNPRS, Ethiopia, master thesis, p.35-42.

Girmay, M., Helmut, K., and Worku, M. (2017). Piped water supply interruptions and acute diarrhea among underfive children in Addis Ababa slums, Ethiopia: A matched case-control study. International Journal of Civil engineering, 4(8), pp.9-18.

Haziq, M., and Panezai, S. (2017). An Empirical Analysis of Domestic Water Sources, Consumption and Associated Factors in Kandahar City, Afghanistan, p ISSN:2163-2618 e-ISSN:2163-2634, 7(2): pp 49-61.

Hussien, W., Memon, F., and Savie, D. (2016). Assessing and modelling the influence of household characteristics on per capita water consumption. Water Resour. 
Manag. 30, 2931e2955, pp 7-28.

Iraj, K., and Rao, P. (2016). water resources and sources for safe drinking and improved sanitation in Ethiopia. International Journal of Applied Research, V.2, Issue.5, pp 12-15.

Jeandron, A., Saidi, M., Kapama, A., Burhole, M., Birembano, F., and Vandevelde, T. (2015). Water supply interruptions and suspected cholera incidence: A time-series regression in the Democratic Republic of the Congo. PLoS Med; 12(10): e1001893. Pmid: 2650

Kassa, M. (2017). Evaluation of water supply and demand: The case of Shambu town, Western Oromia, Ethiopia. International Journal of Water Resources and Environmental Engineering, Vol 12, Issue 32, pp.4-32.

Kumar, M., and Desta, G. (2018). Assessing the challenges of water supply and consumption systems of Tora town, SNNPR, Ethiopia, 6(5), pp 35-52, www.jetir.org.

Manoj, P., and Junil, A. (2015). Issues, challenges and prospects of water supply in urban India. Journal of Humanities and Social Science (IOSR-JHSS), Vol 20, Issue 5, pp 68-73.

Marson, M. (2015). Ensuring sustainable access to drinking water in sub-Saharan Africa: conflict between financial and social objectives. World Dev 76: pp 26-39.

Misgana, M. (2015). Rural households`access to domestic water use in the Sbeta hawas district, Oromia region, Ethiopia, master thesis from Addis Ababa University, pp.45-76.

Rathnayaka, K., Hector, M., and Meenakshi, A. (2016). Assessment of Sustainability of Urban Water Supply and Demand Management Options: International Journal of Water Resources and Environmental Engineerin, 12(22), pp 8-16.

Romano, G., Salvati, N., and Guerrini, A. (2016). An empirical analysis of the determinants of water demand in Italy. J. Clean. Prod. 130, 74e81.

Rumalongo, L., Nathengwe, N., and Musyoki, A. (2017). The nature of urban household water demand and consumption in Makhado Local Municipality: A case study of Makhado Newtown. Procedia Environ. Sci. 37, 182-194. [CrossRef].

Schleich, J., and Hillenbrand, T. (2009). Determinants of residential water demand in Germany. Ecol. Econ. 68, 1756e1769, 4(6), pp 3-11.

Singh, O., and Turkiya, S. (2013). A survey of household domestic water consumption patterns in rural semi-arid village, India. Geo Journal, 78 (5), pp 3-17.

Temitope, D., and Oyedotun, T. (2017). Ensuring water availability in Mekelle City, Northern Ethiopia: evaluation of the water supply sub-project. V.7, Issue 7, pp 4165-4168.

William, J., Cosgrove, D., and Loucks, P. (2015). Water management: Current and future challenges and research directions. https://doi.org/10.1002/ 2014WR016869, Volume 12, Iusse.16, pp 13-18. 